\title{
PENDEKATAN PRAGMATIK DALAM NOVEL NEGERI PARA BEDEBAH KARYA TERE LIYE
}

\author{
Wahid Khoirul Ikhwan \\ Universitas Trunojoyo Madura \\ Email:wahidkhoiruli@yahoo.com
}

\begin{abstract}
Abstrak
NovelNegeri Para Bedebah karya Tere Liye menceritakan tentang masalah ekonomi, politik yang dikemas dengan kehidupan modern saat ini. Analsisi novel ini menggunakan pendekatan pragmatik berusaha mengapresiasi karya sastra berdasarkan fungsinya untuk memberikan dan menyampaikan tujuan tertentu kepada pembaca. Tujuan penelitian iniadalah mendeskripsikan novel Negeri ParaBedebah karya Tere Liye dengan pendekatan pragmatik. Metodepenelitian ini menggunakan metode kualitatif deskrpsi. Sedangka, hasil penelitian ini a dalah pembaca dapat memperoleh nilai-nilai tentang Negeri Para Bedebah yang menggambarkan tokoh-tokoh bed ebah atau celaka dalam novel ini. Selain itu, pembaca juga dapat mengemabil hikmah tentang kepedualian terhadap keluaga, kehidupan politik politikus, dan berkhianat untuk keserakahan.
\end{abstract}

Kata Kunci:pendekatan pragmatik, novel, pembaca.

\section{PENDAHULUAN}

Karya sastra merupakan perwujudan ide, pengalaman, pemikiran, perasaan, dan keyakinan pengarang. Sehingga, karya sastra memiliki makna atau pesan yang akan disampaikan kepada pembacanya dengan cara yang berbeda. Menurut Suharianto (1982:17) bahwa karya sastra sebagai media pengarang untuk mengkomunikasikan sesuatu kepada pembacanya. Pengarang mengkomunikasi kepada pembaca dengan menyampaikan perasaan-perasaan yang dirasakan pada waktu bersentuhan dengan kehidupan. oleh sebab itu, kehadiran karya sastra kan menambah pengalaman batin pembacanya.

Pengalaman batin pembaca dapat diperoleh pembaca dengan memahami pesan yang di karya sastra. Menurut Selden (dalam Endraswara, 2008 : 70) karya sastra tidak mempunyai keberadaan sampai karya sastra itu dibaca, pembaca akan menerapkan kode untuk menyampaikan pesan. Hal ini dipertegas oleh Chairul Harun (dalam Fananie, 2000:13) karya sastra bukanlah juru bicara resmi dari ideologi, doktrin, norma, atau nilai-nilai, karena pada dasarnya sastrawan tidak menginginkan pembaca menjadi anarkis, nihilis, atau menjadi antisrtuktur. Secara umumnya, pesan yang terdapat dalam karya sastra merupakan sebuah penyadaran terhadap berbagai macam kehidupan manusia sebagai fenomena sosial. Hal ini sesuai dengan pendapat Michael Zerafta (dalam Fananie, 2000:14) bahwa bentuk dan isi karya sastra sebenarnya memang lebih banyak diambil dari fenomena sosial dibandingkan dengan seni yang lain, kecuali film. Itulah sebabnya, karya sastra sering kali tampak terikat dengan momen khusus dalam sejarah masyarakat

Salah satu karya sastra sarat mengandung pesan dalam kehidupan modern ini adalah novel Negeri Para Bedebah karya Tere Liye. Novel ini menceritakan tentang masalah ekonomi, politik yang dikemas dengan kehidupan modern saat ini dengan berbagai nuansa kekeluargaan, persahabatan, dan pengkhianatan. Cerita novel Negeri Para Bedebah karya Tere Liye menyajikan petualangan penuh aksi dengan tokoh utama Thomas. Tokoh Thomas adalah seorang konsultan keuangan profesional yang terkenal. Bahkan, tokoh Thomas sudah biasa menjadi pembicara - pembicara di acara berkelas. Tokoh Thomas memiliki perusahaan konsultan yang telah dikenal dikalangan pebisnis dan politikus. Dari tokoh Thomas tersebut alur berkembang dengan usaha menyelamatkan bank milik pamannya yaitu Om Liem. Dengan kepintaran, keberanian, licin, dan kemampuan mempengaruhi orang lain, tokoh Thomas mampu menyelamatkan bank milik pamannya.

Novel Negeri Para Bedebah karya Tere Liye sangat menarik untuk dibaca oleh pembaca. Pembaca tertarik cerita ini bukan hanya masalah cerita yang menghibur, tetapi pesan yang terkandung dalam cerita tersebut. Pembaca sebagai pemberi makna karya sastra tentu mengetahui tugas dan batas dalam memaknai karya sastra. oleh karena itu, hubungan pembaca dan karya sastra sangat menarik dikaji. 
Dalam menganalisis karya sastra berdasarkan teori, ada beberapa pendekatan yang dapat diterapkan melalui pendekatan sastra. Menurut Abram (Jabrohim, 2012: 67) model pendekatan itu terbagi ke dalam empat kelompok, yaitu: Pertama, pendekatan ekspresif, yaitu model pendekatan yang menonjolkan kajiannya terhadap peran pengarang sebagai pencipta karya sastra. Kedua, pendekatan pragmatik, yaitu model pendekatan yang menitikberatkan sorotannya terhadap peranan pembaca sebagai penyambut dan penghayat karya sastra. Ketiga, pendekatan mimetik, yaitu pendekatan yang lebih berorientasi pada

aspek referensial dalam kaitannya dengan dunia nyata. Keempat, pendekatan objektif, yaitu pendekatan yang memperhatikan karya sastra sebagai struktur dengan koherensi intirinsik (melihat struktur karya sastra tersebut).

Berdasarkan empat pendekatan di atas maka penelitian ini lebih memfokuskan pada pendekatan pragmatik. Pendekatan pragmatik sangat bermanfaat terhadap pembaca. Dengan mempertimbangkan indikator karya sastra dan pembaca, maka masalah yang dapat dipecahkan melalui pendekatan pragmatik diantaranya adalah berbagai tanggapan masyarakat tertentu terhadap sebuah karya sastra. Hal ini sesusi dengan pendapat Wahyudi (2008:190) bahwa pendekatan pragmatik merupakan kajian sastra yang membahas secara konkret tentang peranan pembaca dalam menerima, memahami, dan menghayati karya sastra Karya sastra yang hadir di hadapan pembaca akan memiliki daya komunikasi yang ditimbulkan oleh isi yang disampaikan melalui bahasa. Pembaca karya sastra yang memilki latar belakang kemampuan berbeda-beda dapat menangkap kesan, makna, dan manfaat dari isi karya sastra tersebut. Penekanan kepada pembaca ini semakin mendapatkan tempatnya melalui sifat sastra yang multitafsir sehingga pembaca memperoleh banyak kemungkinan makna.

Selain itu, keberhasilan pendekatan pragmatik dapat dilihat dari sejauh mana karya sastra berguna bagi pembaca atau masyarakat tentang pelajaran moral, agama maupun fungsi sosial lainnya. Pendekatan ini mengacu pada pembaca, bahwa keberhasilan suatu karya diukur dari pembacanya. Seberapa jauh pembaca dapat mengambil pelajaran dari karya tersebut. Hal ini sejalan dengan pendapat Yudiono (2009:44) bahwa pendekatan dalam kritik pragmatik menelaah manfaat karya sastra bagi masyarakat atau publik pembaca seperti menyenangkan, menghibur, atau mendidik. Secara tidak langsung, pembaca sebagai penikmat karya sastra tidak hanya mendapatkan hiburan saja, tetepai akan mendidik pembaca untuk berpikiran kritis terhadap pesan-pesan teks yang disampaikan pengarang dalam karyanya

Oleh karena itu, kajian pragmatik ini sangat menarik jika dihubungan novel Negeri Para Bedebah karya Tere Liye. Pembaca akan terbuka pandangan pemikirannya dengan memberikan tanggapan atu reseptif dari novel tersebut dengan liku-liku kehidupan modern yang mengakat masalah ekonomi dan politik yang sebenarnya.

\section{METODE PENELITIAN}

Penelitian ini menggunkan metode kualitatif bersifat deskripsi. Menurut Moleong (2007:11) metode kualitatif merupakan penelitian yang datanya berupa kata-kata, gambar, bukan angkaangka. Sedangkan, Endraswara (2011:5) menjelaskan bahwa salah satu ciri penelitian kualitatif dalam kajian sastra adalah penelitian yang dilakukan secara deskripsi berarti berbentuk uraian dalam kata-kata atau gambar, bukan berbentuk angka. Data penelitian ini berupa novel Negeri Para Bedebah karya Tere Liye. Sedangkan, teknik analisis data menggunakan teknik analasis isi. Menurut Milles dan Huberman (1992:17) menjelaskan bahwa teknik analsisi isi merupakan analisis secara berlanjut, berulang, dan terus menerus dengan beberapa tahapan, yaitu reduksi data, penyajian data, dan verifikasi data.

\section{PEMBAHASAN}

Kehadiran pembaca sebagai penikmat karya sastra sangat berpengaruh terhadap eksistensi karya sastra dan pengarang. Pengarang, karya sastra, dan pembaca merupakan satu bagian yang tidak terpisahkan. Pengarang sebagai pencipta karya sastra tidak akan ada artinya tanpa keberadaan pembaca. Pembaca sebagai penikmat karya sastra akan memperoleh pengalaman, hiburan, ilmu, dan nilai-nilai yang terkandung dalam karya sastra. Karena karya sastra sangat sarat dengan makna dan pesan pengarang terhadap pembaca tentang saran, nasihat, dan nilai-nilai yang bersifat mendidik pembaca. Pesan dan makna yang terdapat dalam karya sastra dipandang secara pragmatik sangat bermanfaat bagi pembaca. 
Pendekatan pragmatik digunkan untuk memahami genre karya sastra dengan menyampaikan tujuan-tujuan tertentu pengarang kepada pembacanya. Dan untuk menyampaikan tujuan-tujuan tersebut pengarang mencerminkannya melalui tokoh cerita, baik melalui deskripsi pikiran maupun perilaku tokoh. Menurut Endraswara (2008: 117) pengarang mampu menghibur dan sekaligus mengajarkan sesuatu, membuat pembaca merasa nikmat dan sekaligus ada sesuatu yang dipetik atau memberi gambaran bahwa pembaca mendapatkan manfaat yang mampu mengubah dirinya

Untuk mendalam karya sastra dengan pendekatan pragmatik Endraswara(2003: 116) membagi menjadi tiga ranah yaitu Pertama, melibatkan teks dan potensinya untuk memungkinkan dan memanipulasi suatu produk makna. Teks sastra adalah fenomena yang dikonkretkan oleh pembaca. Kedua, dalam proses membaca teks, yang paling penting adalah imajiimaji mental yang terbentuk tatkala menyusun sebuah objek-objek yang kohesif dan konsisten. Ketiga, melalui struktur sastra yang komunikatif diteliti kondisi-kondisi yang memungkinkan muncul dan mengatur interaksi antara teks dan pembaca.

Dalam pembahasan ini akan dikaji tentang novel Negeri Para Bedebah karya Tere Liye dengan pendekatan pragmatik. Pendekatan pragmatik berusaha mengapresiasi karya sastra berdasarkan fungsinya untuk memberikan dan menyampaikan tujuan tertentu kepada pembaca. Ketika pembaca memperoleh banyak nilai atau ajaran yang terdapat dalam karya sastra dan berguna bagi pembacanya, maka akan semakin tinggi nilai dari karya sastra tersebut.

Secara langsung ketika membaca novel Negeri Para Bedebah karya Tere Liye akan memperoleh beberapa aspek pragmatik anatar lain sebagai berikut.

\section{Negeri Para Pedebah}

Dari judul novel Negeri Para Bedebah, sebenarnya pembaca sudah bisa menafsirkan isi cerita. Hal ini bisa dilihat dari kata yang digunkan dalam judul negeri artinya tanah atau wilayah tempat tinggal suatu bangsa. Selanjutnya kata para yang merupakan pengacuan ke kelompok tertentu dan kata bedebah mepunyai arti celaka sebagai kata makian. Bisa digambarkan dari arti judul novel Negeri Para Bedebah adalah bangsa yang mengacu pada orang atau kelompok tertentu yang celaka. Dalam novel ini juga digambarkan tokoh-tokoh yang dikatakan sebagai bedebah seperti tokoh Om Liem. Om Liem bisa dikatakan sebagai salah satu orang bedebah, karena Om Liem seorang pengusahan yang memiliki bank semesta. Om Liem dalam menjalanakan bisnisnya bersifat serakah dan melanggar peraturan-peraturan demi mengembangkan bisnisnya. Om Liem menempuhnya untuk melancarkan bisnisnya termasuk membantu keuangan salah satu partai politik demi melancarkan usaha bisnisnya, seperti kutipan di bawah ini.

"Aku juga tahu bahwa terlalu banyak transaksi tidak bisa dijelaksan di bank itu. Enam tahun menguasai bank itu, Om Liem terlalu ambisius, tidak hati-hati, menggampangkan banyak hal, dan melanggar begitu banyak regulasi demi pertumbuhan bisnisnya. Ram kembali menghela napas". (TR, 2012:41).

Selain itu, ada juga tokoh yang termasuk bedebah yaitu Tokoh bernama Tuan Shinpei ialah otak dari segala masalah yang mengakibatkan bisnis Om Liem bangkrut. Serta tokoh Wusdi adalah seorang petinggi polisi dan dan tokoh Tunga yaitu seorang Jaksa senior. Tokoh Wusdi dam tokoh Tunga merupakan pejabat menyalahgunkan wewenang dan kekuasaan untuk mendapatkan tujuan yakni meraup uang sebanyak-banyaknya. Selain itu, kedua tokoh juga terlibat pembakaran rumah Thomas sehingga papa dan mamanya meninggal. Hal ini sesuai dengan kutipan di bawah ini.

Dua bedebah itu menjadi orang penting di negeri ini. Satu menjadi bintang tiga kepolisian, hanya soal waktu dia jadi kepala polisi. Satunya lagi jaksa paling penting dan berpengaruh di korpsnya, hanya soal waktu menjadi jaksa agung. Aku kembali, Julia. Sejak tadi malam aku memutuskan kembali ke keluarga ini. Aku akan membalaskan setiap butir debu jasad Papa-Mama........(TR, 2012: 118).

Selanjutnya, ada tokoh yang termasuk bedebah yaitu tokoh Ram. Tokoh Ram merupakan salah satu pekerja yang bekerja dengan Om Liem. Bahkan, tokoh Ram dianggap oleh Om Liem sebagai keluarga dan disekolahkan juga oleh Om Liem. Tokoh Ram dikatakan Bedebah karena tokoh Ram ini ternyata berkhianat kepada Om Lim. Bentuk pengkhianatanya yaitu tokoh Ram ini berusaha menguasai aset-aset Om Lien di Hongkong 
dengan cara menyandra Thomas dan Om Liem ketika melarikan diri dari Indonesia.

Selain itu, ada juga tokoh yang termasuk bedebah, yaitu tokoh utama dalam novel ini yaitu tokoh Thomas. Tokoh Thomas ini bisa dikatagorikan sebagai bedebah karena berusaha membantu melarikan diri pamannya, tokoh Om Liem. Thomas melarikan paman dan Opanya dengan segala cara, dikejar-kejar polisi, bolakbalik bandara kesana sini mengurusi persoalan itu. Hal ini sesuai dengan kutipan di bawah ini.

"Ram kau tetap tinggal di sini. Pastikan kau mengurus Tante. Kalian tahan polisi selama kalian bisa, berbual, karang alasan, bilang Om Liem tiba-tiba sakit perut, ada di toilet, atau bilang Om Liem memanjat jendela, kabur ke taman belakang. Beri kami waktu lima belas menit menuju bandara, Ram. Pastikan kau membangunkan salah satu staf perusahaan untuk menyiapkan tiket, paspor, dan dokumen perjalanan kami. Segera menyusul ke bandara. Ada penerbangan ke Frankfurt, transit di Dubai pukul 3 dini hari, 45 menit lagi. Kita lakukan demi Om Liem, orang yang telah membantu banyak kalian (TR, 2012:51).

Berdasarkan tokoh-tokoh yang termasuh sebagai bedebah setidaknya memberikan isyarat kepada pembaca bahwa dalam menjalani kehidupan harus meninggal nilai-nilai yang serakah, egoisme, korupsi, mementingkan kepentinga pribadi, dan, menyalahgunakan wewenang. Selain itu, pembaca juga dapat memberikan pelajaran bahwa dalam menjalani kehidupan ini harus mentaati peraturan-peraturan yang telah ditetapkan oleh negara.

\section{Peduli terhadap Keluarga}

Novel Negeri Para Bedebah karya Tere Liye juga menceritakan tentang kepedulian terhadap keluarga. Hal ini digambarka pada tokoh Thomas. Tokoh Thomas merupakan konsultas yang sukses dan terkenal diseluruh dunia. Tokoh Thomas sering diundang menjadi pembicara di beberapa negara. Di samping sebagai konsultan terkenal, tokoh Thomas juga peduli terhadap keluarganya. Hal ini ditunjukkan ketika pamannya, Om Liem, menghadapi kebangkrutan usahanya, yaitu Bank Semesta.

Sebenarnya tokoh Thomas tidak mau berurusan dengan pamannya, karena tokoh Thomas sangat membencinya. Tetapi, tokoh
Thomas mau menolong pamannya yang sedang di kepung oleh polisi. Thomas berencana membawa pamannya dan bibinya meninggalkan rumah dengan diam-diam. Tokoh Thomas membawa kabur paman dan bibinya sebagai usaha untuk menyelamatkan Bank Semesta, karena tanpa tanda tangan pamannya sebagai pemilik Bank Semesta tidak akan dibekukan. Hal ini sesuai dengan kutipan di bawah ini.

"Bilang ke polisi di luar, kondisi Tante Liem semakin parah. Aku menarik salah satu perawat itu sebelum keluar dari ruangan. Kalau mereka bertanya detail, jangan dijawab, dan jangan pernah biarkan mereka mendekati pintu kamar ini. Kau mengerti? Perawat itu mengangguk meski masih dengan wajah bingung. Apa..apa yang sedang kaulakukan, Tom? Om Liem bertanya gugup. Menyelamatkan seluruh keluarga ini. Apa lagi? Aku berseru cepat. Kau, ya kau bantu melepas infus dari tangan Tante Liem. Segera! Aku meneriaki dua perawat yang tersisa di kamar". (TR, 2012:47-48).

"Kalian tahan polisi selama kalian bisa, berbual, karang alasan, bilang Om Liem tibatiba sakit perut, ada di toilet, atau bilang Om Liem memanjat jendela, kabur ke taman belakang" (TR. 201,:51).

Berdasarkan kutipan di atas tokoh Thomas berusaha menyelamatkan pamanya, Om Liem, dari tangkapan polisi di rumahnya. Tokoh Thomas dibantu dokter dan perawat, serta orangorang yang ada di dalam kamar. Pada akhirnya, tokoh Thomas, paman, dan bibinya bisa melarikan diri dari kepungan polisi.

Tidak hanya membantu pelarian paman dan bibinya, tokoh Thomas juga berhasil menyelamatkan Bank Semesta dari pembekuan oleh pemerintah. Beberapa langkah yang dilakuakn tokoh Thomas untuk menyelamatkan Bank Semesta adalah dengan mengundang beberapa media televisi hingga editor majalah untuk membantu keberhasilannya menyelamatkan bank tersebut. Hal ini sesuai dengan kutipan di bawah ini.

"Kau segera telepon enam-tujuh wartawan surat kabar, majalah, televisi, berita online, yang sering memintaku menjadi narasumber, kolega pers kita. Aku mengabaikan keluhan Maggie, mulai mendikte apa yang harus segera dia lakukan. Kau sertakan juga tiga-empat 
pengamat ekonomi, kawan dekat, yang sering sependapat dengan kita. Minta mereka berkumpul di salah satu restoran hotel dekat kantor, beritahu mereka bahwa kita punya rilis paling rahasia, paling gres tentang kasus Bank Semesta. Jangan tanya detail siapa saja yang harus diundang, Maggie. Ayolah, kau tahu persis harus mengundang siapa. Aku membutuhkan kaki tangan untuk membentuk opini di media massa meskipun mereka sama sekali tidak merasa telah digunakan". (TR, 2012:69).

Berdasarkan kutipan di atas tokoh Thomas memerintahkan Maggie segera telepon enam tujuh wartawan surat kabar, majalah, televisi, berita online, kolega pers serta tigaempat pengamat ekonomi, kawan dekat, yang sering sependapat dengan kita. Dengan membangun opini di media sosial maka Bank Semesta masih beroperasi. Sampai pada akhirnya, tokoh Thomas berhasil menyelamatkan Bank Semesta dari pembekuan.

\section{Kehidupan Politik Politikus}

Selama ini mungkin pembaca hanya mengetahu partai politik ibarat pahlawan yang akan membantu menyuarakan suara rakyat dalam berkehidupan di negara. Para politikus yang menjalankan partai politik selalu terba pesona dihadapan rakyat memberikan janji-janji politik untuk kepentingan partai politik. Bahkan para politikus sering memberikan sumbangan yang berupa matariil untuk rakyat. Ibaratnya palitikus seperti pahlawan yang selalu ada untuk rakyat. Tetapi kenyataannya banyak politikus terlibat dalam kapital birokrat, yaitu berupa politik uang dengan cara memberi uang atau ikut memberi sumbangan kepada partai politik. Sehingga, partai politik menjadi tempat para poitkus untuk menanamkan modol berupa uang di dalam partai dengan harapan dimudahkan dan kedudukannya. Hal ini sesuai dengan kutipan di bawah ini.

"Realitis saja Thom." Dia mengangkat bahu, kami masih basa-basi membicarakan hal lain. "Semua partai membutuhkan banyak uang untuk menggerakkan orang. Siapa yang akan menyediaakan? Partai bukan perusahaan, partai bukan mesian uang. Apakah kader-kader sukarela menyumbang tanpa berharap imbalan? Anggota partai? Mereka tidak akan pernah bersedia menyumbang jika tidak mendapat sesuatu. Kekuasaan misalnya. Posisi, akses, jaringan, atau perlindungan. Termasuk individu atau perusahaan yang bukan anggota, mereka hanya partisan partai tapi tidak mendukung, mereka menuntut sesuatu."(TR, 2012:382).

Berdasarkan kutiapn di atas dapat digambarkan bahwa sumbangan poitikus ke partai politik tidak gratis. Tidak hanya para politikus, para pengusaha baik itu perseorangan atau kelompok juga terlibat di dalamnya dengan berharap mendapat kedudukan, akses, jaringan, dan perlindungan.

Pada prinsipnya, pembaca dengan membaca novel ini bisa menjadi sadar bahwa partai politik dan politikus merupakan kelompok atau individu yang memiliki kepentingankepentingan individual. Politikus atau partisipan memberikan mahar politik yang berupa uang ke partai politik sebagai modal penggerak partai untuk kemenangan partai. Namun, semua itu tidak cuma-cuma, mereka mengharapkan balasan yang pada masa yang akan datang baik kedudukan, akses untuk memuluskan usaha mereka dan lain-lain. Hal ini dibuktikan dengan kutipan di bawah ini.

"Nah, kalau kau punya uang, itu bisa diatur. Kau tinggal setor berapa miliyar untuk partai, sisanya kami yang urus. Jadi jangan heran, walaupun kau gagal, andaikata bertahun-tahun kemudian keluargamu terjerat kasus hukum misalnya, partai yang pernah mendukungmu tentu tahu diri melakukan balas budi" (TR, 2012:384).

Berdasarkan kutipan di atas dapat memberikan gambaran kepada pembaca bahwa kehidupan politik dan politikus di negeri ini sangat menjijikkan dan memalukan. Pembaca akan dengan mudah memberikan interpretasi terhadap novel ini terutama pada prilaku pejabat pemerintahan, partai politik, politikus yang tentunya tidak diharapkan oleh rakyat. Karena mereka berprinsip uang, jabatan, dan kedudukan adalah segala-galanya dalam kehidupan ini. Uang, jabatan, dan kedudukan untuk kepentingan pribadi atau kepentingan kelompak. Dengan semuanya bisa dilakukan untuk memperoleh kedudukan, akses jaringan, melancarkan bisnis, bahkan bisa melepaskan dari jeratan hukum. 


\section{Volume 6 No. 1 METALINGUA \\ April 2021 Jurnal Pendidikan Bahasa dan Sastra Indonesia}

\section{Berkhianat untuk Keserakahan}

Kehidupan ini tidak lepas dari interaksi antarmanusia. Interaksi tersebut menyebabkan masalah atau konflik. Salah satu konflik dalam interaksi kehidupan adalah pengkhiantan. Pengkhianatan tentunya akan menyakiti orang yang dikhiatani, terlebih yang dikhianati adalah sahabat, keluarga ataupun orang kepercayaan.

Novel ini juga menyajikan pengkhiatan untuk mencapai keserakahan pribadi antartokoh dalam novel. Tokoh Ram terlibat dalam pengkhianatan terhadap rekanya sendiri yaitu Wusdi dan Tunga. Tokoh Ram membunuh Wusdi dan Tunga dengan harapan bisa menegambil keuntungan dari pailitnya Bank Semesta. itu dibuktikan dengan kutipan berikut.

"Hanya mengamankan bagianku. Semuanya". Ram menyeringai. "Kau....kau pengkhianat...!! Tunga mendesis. Disebelanya bahkan Wusdi sudah tidak lagi mengeluarkan suara. "Ayolah siapa yang pengkhianant" Ram nelempar gelas plastik berisi teh panas yang telah dicampur dengan racun (TR, 2012: 426)

"Bukankah dia punya banyak kenalan orang penting dan berkuasa untuk menyelamatkan bank itu? Akhirnya aku berkomentar. Ram tertawa masam. "Dia punya lebih banyak musuh dan orangorang yang ingin mengambil keuntungan dari kolapsnya Bank Semesta, Thom. Mereka berebut ingin mendapatkan aset berharga yang dijual murah. Dia sudah terdesak". (TR, 2012:41-42).

Selain itu, tokoh Ram juga mengkhianati keluarga Om Liem. padahal tokoh RAM adalah karyawan kepercayaan keluarga Om Liem. Bahkan, tokoh Ram juga tega mengkhianati Opa sebagai orang yang telah berjasa mendidik dan membesarkan Ram. Tanpa belas kasihan tokoh Ram melempar Om liem ke tengah laut, saat kapal menuju ke Hongkong. Hal itu dibuktikan dengan kutipan berikut.

"Maafkan aku Opa. Kalian sudah tidak dibutuhkan lagi di atas kapal " Ram menatap Opa. "waktu kita tidak banyak, Opa. Loncat atau kutembak!” Ram membentak. (TR, 2012:430).

Orang-orang yang melakukan pengkhianatan demi keserakahan terhadap orang lain tentunya akan merugikan orang lain. Seperti tokoh Ram yang berkhianat terhadap teman Wusdi dan Tunga serta Om Liem tentunya akan merugikan tokoh-tokoh yang dikhianati. Kerugian yang yang dialami Wudi dan Tunga akhirnya dibunuh oleh tokoh Ram. Sedangkan, tokoh Om Liem harus dibuang di laut. Oleh karena itu, pembaca bisa mengambil nilai-nilai akibat prilaku pengkhianatan untuk dijadikan koreksi diri-sendiri untuk tidak dilakukan kepada orang lain.

\section{PENUTUP}

Berdasarkan analisis teks sastra terhadap novel Negeri Para Bedebah karya Tere Liye, dapat disimpulkan bahwa pembaca akan mampu menginterpretasikan makna dan pesan pengarang terhadap pembaca tentang saran, nasihat, dan nilai-nilai yang bersifat mendidik pembaca. Berdasarkan isi novel Negeri Para Bedebah karya Tere Liye pembaca dapat memperoleh nilai-nilai tentang Negeri Para Bedebah yang menggambarkan tokoh-tokoh bedebah atau celaka dalam novel ini. Selain itu, pembaca juga dapat mengemabil hikmah tentang kepedualian terhadap keluaga, kehidupan politik politikus, dan berkhianat untuk keserakahan.

\section{REFERENSI}

Endraswara .2011. Metodelogi Penelitian Sastra.Yogyakarta: Caps.

Endraswara, Suwardi. 2008. Metodologi Penelitian Sastra. Yogyakarta: PustakaWidyatama.

Fananie. 2012. Telaah Sastra .Bandung: Gramedia Pustaka Utama.

Jabrohim (Ed.). 2012. Teori Penelitian Sastra. Yogyakarta: Pustaka Pelajar.

Miles, Mathew B. Dan A. Michael Huberman. 1992. Analisis Data Kualitatif : Buku Sumber tentang Metode-Metode Baru. Terjemahan Tjetjep Rohendi Rohidi. Pendamping, Mulyarto. Cet. I. Jakarta : UI Press.

Moleong, Lexy J. 2007. Metodologi Penelitian Kualitatif. Edisi Revisi. Bandung : PT Remaja Rosdakarya.

Suharianto .1982. Dasar-dasar teori sastra. Surakarta: Widya Duta.

Wahyudi Siswanto.2008. Pengantar Teori Sastra. Jakarta:PT Grasindo.

Yudiono K.S. .2009. Pengkajian Kritik Sastra Indonesia. Jakarta: Grasindo. 